University of Nebraska - Lincoln

DigitalCommons@University of Nebraska - Lincoln

1986

\title{
Discovery of Two Additional Prosimian Primate Families (Omomyidae, Lorisidae) in the African Oligocene
}

\author{
Elwyn L. Simons \\ Duke University \\ Thomas M. Bown \\ U.S. Geological Survey \\ D. Tab Rasmussen \\ Duke University
}

Follow this and additional works at: https://digitalcommons.unl.edu/usgsstaffpub

Part of the Earth Sciences Commons

Simons, Elwyn L.; Bown, Thomas M.; and Rasmussen, D. Tab, "Discovery of Two Additional Prosimian Primate Families (Omomyidae, Lorisidae) in the African Oligocene" (1986). USGS Staff -- Published Research. 244.

https://digitalcommons.unl.edu/usgsstaffpub/244

This Article is brought to you for free and open access by the US Geological Survey at DigitalCommons@University of Nebraska - Lincoln. It has been accepted for inclusion in USGS Staff -- Published Research by an authorized administrator of DigitalCommons@University of Nebraska - Lincoln. 
Elwyn L. Simons

Duke University Primate Center, Durham, North Carolina, 27705, L.S.A.

\section{Thomas M. Bown}

I:S. Geological Survey, Denver, Colorado, 80225, U.S.A.

\section{Tab Rasmussen}

Duke University Primate Center, Durham, North Carolina, 27705, L.S.A.

Received 18 September 1986 Revision received 5 January 1987 and accepted 6 January 1987

Publication date June 1987

Keywords: Omomyidae, Lorisidae, primate evolution, Oligocene primates.

\section{Discovery of Two Additional Prosimian Primate Families (Omomyidae, Lorisidae) in the African Oligocene}

\begin{abstract}
Three new specimens reported here are referable to the Omomyidae and Lorisidae, and represent only the second and third prosimian primates found in the Oligocene rocks of the Fayum, Egypt. The Fayum omomyid extends the range of the Omomyidae into Africa, while the Fayum lorisid is the oldest record of the Lorisidae world-wide. Afrotarsius established ?Tarsiidae as a third prosimian family present in Oligocene rocks of the Fayum region of Egypt (Simons \& Bown, 1985). These new occurrences significantly reorient paleogeographic study of primate origins. In a fauna famed for the presence of about a thousand specimens of early Anthropoidea-viz. Apidium, Parapithecus, Qatrania, Propliopithecus, Oligopithecus, and Aegyptopithecus, the three prosimian families are documented to date from only four specimens. Among all major groups of living and fossil euprimates, only the Malagasy lemuriforms, the Adapidae, and the New World monkeys now have no fossil record in the Oligocene of Egypt, making the Fayum area the most diverse in terms of primates of any region in the world.
\end{abstract}

Journal of Human Evolution (1986) 15, 431-437

\section{Introduction}

The celebrated Oligocene primate fauna from Egypt was first reported by Osborn (1908) and by Schlosser (1911) three-quarters of a century ago. This was greatly enlarged in the last twenty-five years by expeditions led by the senior author, but only anthropoidean primates were known until the discovery of Afrotarsius (Simons \& Bown, 1985). After extensive collecting over many years, the absence of Fayum prosimians was difficult to explain because several Fayum localities yield micromammalian remains in abundance. Moreover, the Fayum region is geographically about equidistant between the centers of modern prosimian distribution and, during the Oligocene, was located in the tropical zone. Now, not long after description of $A$ frotarsius we are here able to document the first records of two additional prosimian families (Omomyidae and Lorisidae) in the Oligocene of Egypt.

The new Fayum omomyid belongs in the subfamily Anaptomorphinae, a diversified early Tertiary group of primates (Szalay, 1976). Anaptomorphines are well known in early to late Eocene faunas of North America and the early Eocene of Europe. Altanius is an apparently early Eocene genus from Mongolia that was originally placed in the Anaptomorphinae (Dashzeveg \& McKenna, 1977) but which has more recently been referred to the Plesiadapiformes (Rose \& Kraus, 1984). Though poorly known, middle or late Eocene Kohatius from Pakistan is a certain Asian record of the Anaptomorphinae (Russell \& Gingerich, 1980). Fossils of the living family Lorisidae are otherwise known exclusively from Miocene and younger rocks of East Africa (Simpson, 1967; Walker, 1974, 1978; Wesselman, 1984) and the Miocene of southern Asia (Jacobs, 1981; MacPhee \& Jacobs, 1986). In this paper, we describe the first omomyid primate ever found in Africa (Anaptomorphinae) and the earliest record of the Lorisidae. The authors are aware that naming fossil taxa on the basis of isolated teeth is less than ideal and have therefore 
deferred formal systematic treatment at this time. However, because of the great rarity of these specimens (only three teeth out of tens of thousands of fossils recovered in the Fayum across a quarter century), we believe that description of the specimens now is warranted, rather than waiting for better material.

\section{The Fayum Omomyid}

Two teeth referable to the Omomyidae have been recovered from quarry $\mathrm{E}$, which lies at the 93 meter level of the Jebel Qatrani Formation (see Fleagle et al., 1986): DPC (Duke Primate Center) 5403, a left lower fourth premolar [Figure 1(a)] and DPC 2809, a left upper fourth premolar [Figure 1(b)].

Figure 1. SEM stereomicrographs

$(\times 20)$ of the Fayum omomyid

specimens, occlusal aspect: (a) DPC 5403, left $\mathrm{P}_{4}$; (b) DPC 2809, left $\mathrm{P}^{4}$.
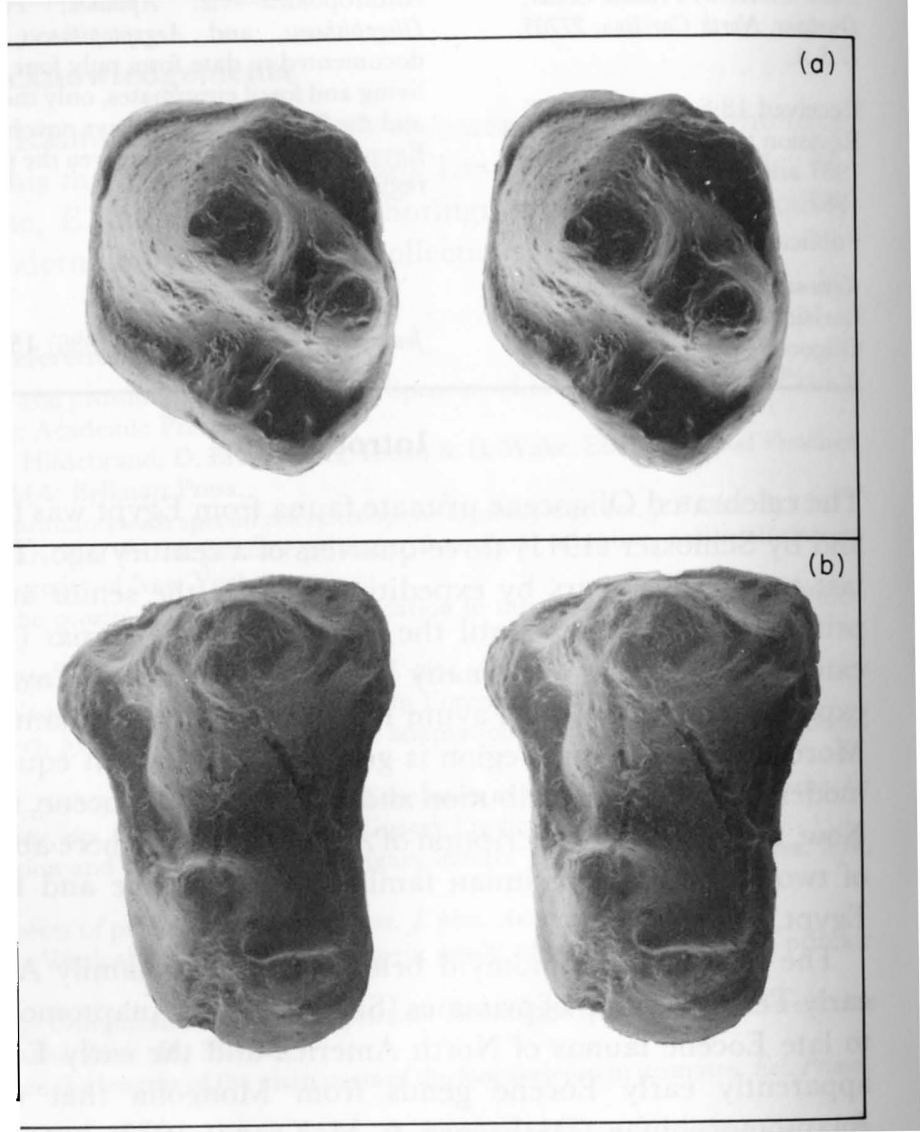

The combination of the well developed paraconid and metaconid, the poorly defined paracristid, the posterolingual expansion of the talonid region of the crown, and the overall swollen or inflated appearance of the crown of $\mathrm{P}_{4}$ clearly diagnose the lower premolar of the Fayum omomyid from other primates and serve to place it in the Anaptomorphinae (Szalay, 1976). Aside from being much larger and possessing a more internally situated protocone, the fourth upper premolar is virtually indistinguishable from that in Euramerican Teilhardina. 
The following diagnostic features of these teeth serve to differentiate the Fayum omomyid from North American and European members of the family: Paraconid and metaconid on $\mathrm{P}_{4}$ larger than in Tarsius, Tetonius, Nannopithex, and Teilhardina, with the metaconid developed about as in Anemorhysis pearcei and the paraconid slightly smaller than in Anemorhysis, but larger than in Pseudoloris. Lower fourth premolar with raised posterobasal heel in contrast to Tarsius and $\mathrm{P}_{4}$ crown broader and with more posterolingual inflation than in Tarsius, Teilhardina, Pseudoloris, and Nannopithex, resembling that in Tetonius. Trigonid less linguolabially compressed than in $\mathrm{P}_{4}$ of Teilhardina and Nannopithex, and with ectocingulid prominent as in some Anemorhysis and Teilhardina. Lower fourth premolar differs from that in Anemorhysis in lacking small posterolingual talonid basin and from that in Pseudoloris in having a more constricted talonid and in lacking a well developed paracristid. In the Fayum omomyid, $\mathrm{P}_{4}$ is larger and more inflated than in all of the above forms and possesses a somewhat more oblique postvallid. The upper fourth premolar very closely resembles its counterpart in Teilhardina, except for being much larger and with a more internally situated protocone; the last feature is unique among the Tarsiiformes. Measurements $(\mathrm{mm})$ are: $\mathrm{P}_{4}$, length $=2 \cdot 50$, breadth $=2 \cdot 05$, crown height $=2 \cdot 70 ; \mathrm{P}^{4}$ length $=2 \cdot 50$, breadth $=3 \cdot 70$.

Among the anaptomorphine primates, the Fayum omomyid shares a crossing complex of characters seen individually in Teilhardina and in North American Anemorhysis and Tetonius. The large metaconid and paraconid reflect the relative sizes and configurations of the same features in Anemorhysis pearcei (Gazin, 1962) and a new, as yet unnamed species of Teilhardina from the Bighorn Basin of Wyoming (Bown \& Rose, 1986). However, the inflated $\mathrm{P}_{4}$ crown, with its pronounced posterolingual expansion of the talonid region, is most similar to the condition in North American early Eocene Tetonius and Absarokius.

The Fayum omomyid less closely resembles European Pseudoloris and Nannopithex, and is not similar to the microchoerines Necrolemur and Microchoerus. The Fayum omomyid is also clearly distinct from representatives of other fossil prosimian groups, including the Adapidae, Lorisidae, and Tarsiidae, and also from the diminutive anthropoid Qatrania (Simons \& Kay, 1983) from the same locality. The omomyid $\mathrm{P}_{4}$ from quarry $\mathrm{E}$ differs from Qatrania primarily in having: a less bulbous and more symetrical protoconid; a much larger and more conical metaconid; presence of a paraconid and strong ectocingulum, both absent in Qatrania; the broad posterobasal heel that extends lingually beyond the metaconid, unlike the small shelf that ends at a weak postmetacristid in Qatrania; and an overall larger size. The Fayum omomyid is also too large to belong to the ?tarsiid $A$ frotarsius chatrathi (Simons \& Bown, 1985), and what is known of its morphology is omomyid and not tarsiid, as described above. The combination of diagnostic morphologic attributes also seen independently in the anaptomorphines Teilhardina, Anemorhysis, and Tetonius is unique to the Fayum omomyid, as are the oblique anterolabial-posterolingual configuration of the postvallid on $\mathrm{P}_{4}$ and the internally situated protocone on $\mathrm{P}^{4}$. We believe that the lower fourth premolar is the most useful single tooth for identifying members of the anaptomorphine primates.

The two described specimens of the Fayum omomyid are from the same locality, both are omomyid in morphology, they are of approximately the same length, and they occlude very well - all evidence that they probably belong in the same species.

Omomyid primates are now known from Euramerica (where they are best represented and most diverse), Asia, and North Africa. The geographic origin of the group remains 
obscure. Addition of the Fayum specimen as the first African representative of the group now suggests that Africa is an equally likely candidate for its place of origin. This is enhanced circumstantially (as is the case for southern Asia) by the mutual occurrence there of the only two tarsiiform families, the Omomyidae and the Tarsiidae.

\section{The Fayum Lorisid}

One right upper third molar (YPM [Yale Peabody Museum] 23987, Figure 2) referable to the Lorisidae has been recovered from quarry I, which lies at the 244 meter level of the Jebel Qatrani Formation, the same level that yields fossils of the well-known anthropoids Propliopithecus chirobates, Aegyptopithecus zeuxis, Parapithecus grangeri and Apidium phiomense (see Fleagle et al., 1986).

Figure 2. SEM stereomicrograph $(\times 20)$ of the Fayum lorisid specimen, occlusal aspect of YP.M 23987, right $\mathrm{M}^{3}$.

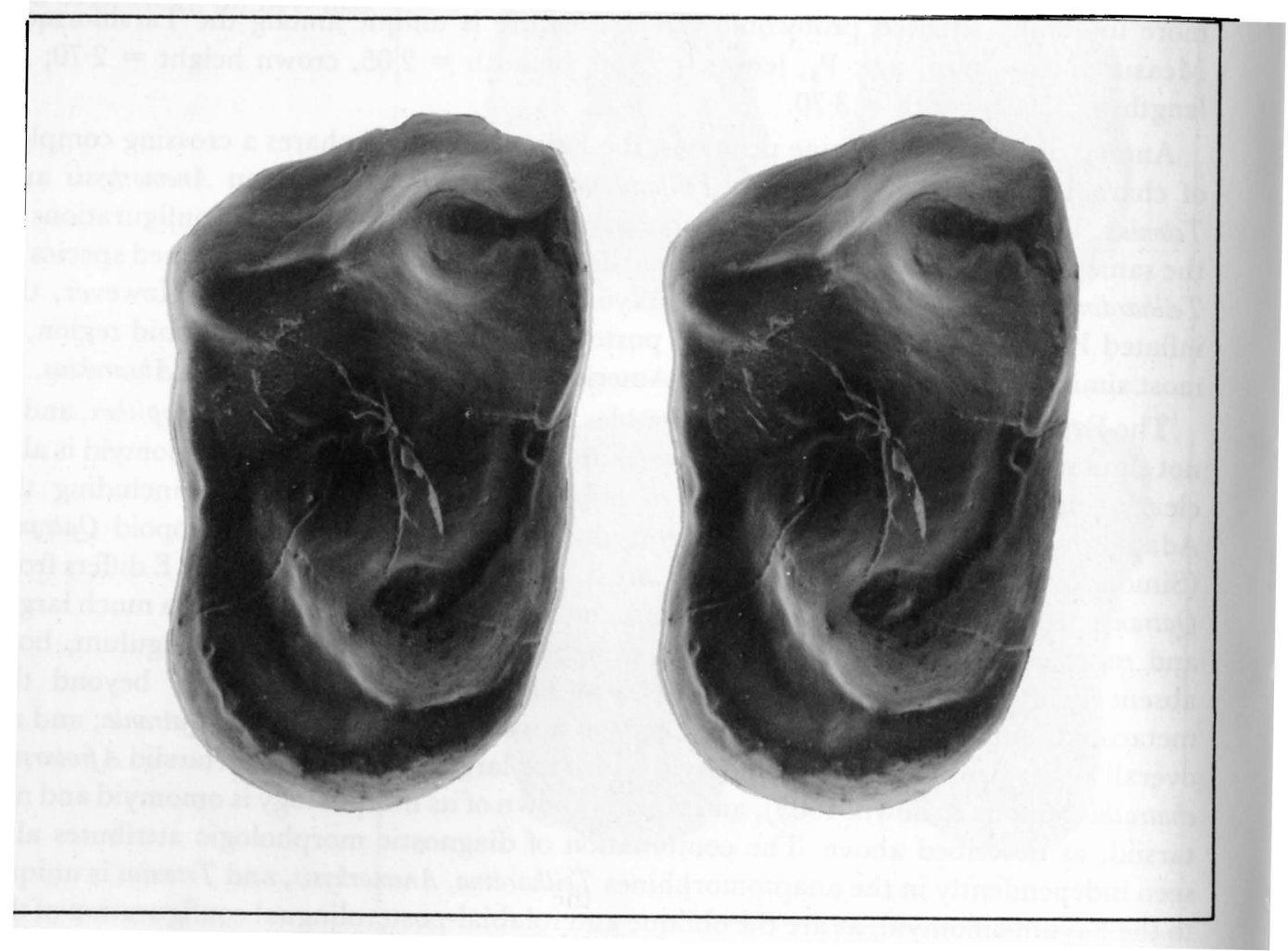

This solitary specimen is referred to the Lorisidae by virtue of its combination of a broad molar basin, a somewhat reduced metacone, the lack of a mesostyle, poorly developed to absent conules, and the greatly enlarged posterolingual and lingual cingulum. Though the $\mathrm{M}^{3}$ of the Fayum lorisid is more transverse with respect to length and more rectangular (less triangular) than in most other lorisids, a very close approximation to this molar outline is seen in extant Arctocebus (Maier, 1980), with which the Fayum specimen shows the greatest general similarity. Like Arctocebus and Nycticebus, the $\mathrm{M}^{3}$ metacone is not displaced as far lingually as in Loris or Galago. 
The Fayum lorisid molar can be distinguished from other members of the Lorisidae by the following features: $\mathrm{M}^{3}$ is more transverse and rectangular than in Nycticeboides, Mioeuoticus, Progalago, Loris, Galago, and Nycticebus, and with much larger lingual and posterolingual cingulum (posterolingual shelf) than in the latter six forms and Arctocebus. The notch separating postparacrista and premetacrista and the deep invagination of buccal margin of ectoflexus seen in Nycticeboides are absent in the Fayum lorisid. Paracone and metacone of the Fayum specimen are connected by confluent postparaconepremetacone cristae, not separated by a valley as in Mioeuoticus. The hypocone is absent, and there is no posterobasal invagination of the $\mathbf{M}^{3}$ crown in contrast to Loris. A metacone is present and moderately large on $\mathrm{M}^{3}$, not reduced to the extent seen in Perodicticus, and the metacone not displaced lingually to the extent seen in Loris and Galago, approximating the conditions in Nycticebus and Arctocebus. Measurements $(\mathrm{mm})$ are: $\mathrm{M}^{3}$, length $=2 \cdot 30$, breadth $=4 \cdot 10$.

Miocene lorisids are known only from lower Miocene rocks of East Africa-the galagines Progalago (MacInnes, 1943) and Komba (Simpson, 1967), the lorisine Mioeuoticus (Leakey, 1962)_-and from the later Tertiary Siwalik series of Pakistan-the lorisine Nycticeboides simpsoni and unnamed forms (Jacobs, 1981; MacPhee \& Jacobs, 1986). The greater resemblance of the Fayum lorisid to lorisines rather than to Galago, Komba, or Progalago cannot be considered as strong evidence favoring an early divergence of lorisines and galagines because the unique configuration of galagine molars may be more recently derived. Among the fossil lorisines, the Fayum lorisid most closely resembles Mioeuoticus, and is least similar to Nycticeboides. The size of $\mathrm{M}^{3}$ in the Fayum lorisid suggests a larger-bodied animal than any modern lorisids; however, size reduction of $\mathrm{M}^{3}$ has occurred to varying degrees in fossil and modern lorisids, and so body size cannot be confidently gauged from isolated third molars.

Several derived characters of $\mathrm{M}^{3}$ that are widely distributed among the Adapidae (mesostyles, hypocones, pericones) are absent in the Fayum lorisid. Moreover, the presence of a paracone that is much larger than the metacone and a metacone that is somewhat deflected in the lingual direction with respect to the paracone are more lorisid than adapid attributes. Outside the Lorisidae, perhaps the closest similarity to the Fayum specimen is seen in some of the Eocene Omomyidae of North America, especially Omomys carteri (see Szalay, 1976).

Simpson (1967), Walker (1974, 1978) and MacPhee \& Jacobs (1986) have discussed the oldest members of the Lorisiformes prior to the description of the Fayum specimen which, with an age well exceeding 31.0 Mya (Fleagle et al., 1986) is certainly the oldest known member of that group. Discovery of a lorisid in the early Oligocene of Egypt adds nothing to our knowledge of the phyletic origins of the Lorisiformes, as the specimen bridges no morphological gaps between lorisids and other groups. However, the presence of a lorisid in Africa at such an early date suggests that the tooth-combed prosimians had evolved for some time in Africa independently of North American and European Adapidae.

The Fayum lorisid does document at the very least that the lorises had diverged from lemuriform prosimians by the early Oligocene (unless the distinctive dental morphology of lorisids proves to be primitive for tooth-combed prosimians in general) and that their dispersion by that time had come to embrace one of the two continents included in their modern distribution. The central geographic position of the Fayum of Egypt with respect to modern lorisiform distribution underscores the likelihood that the region played an 
important role in early lorisoid evolution. The presence in the Fayum of an early representative of both the Lorisidae and Tarsiidae, the only two prosimian families still extant in Asia, adds to the evidence indicating faunal and floral similarities between the Oligocene Fayum and modern South Asia, as documented also by plants such as the liane Epipremnum, and the crocodilian Tomistoma (Bown et al., 1982).

\section{Conclusions}

(1) A lower fourth premolar and an upper fourth premolar from quarry $\mathrm{E}$ of the Jebel Qatrani Formation, Fayum, Egypt, are refered to the Anaptomorphinae, a diverse early Tertiary group of tarsiiform prosimians. These finds represent the first record of the Omomyidae in Africa.

(2) An upper third molar from quarry I of the Jebel Qatrani Formation is referred to the Lorisidae, a family otherwise known from the Miocene to Recent of Africa and Asia. The Fayum specimen thus represents the earliest ( $>31 \mathrm{Mya}$ ) record of the family worldwide.

(3) These two occurrences are the second and third prosimian primates identified from the Fayum. Other primate groups known from the Fayum include the Tarsiidae, Parapithecidae, and the Propliopithecidae, thus making the Fayum area the most diverse in terms of primates of any region in the world.

(4) The new finds suggest that Africa may have been an important center of prosimian evolution and radiation, as it certainly was also in the case of anthropoidean evolution.

\section{Acknowledgements}

We thank K. D. Rose, F. A. Ankel-Simons, C. A. Repenning and F. S. Szalay for review of the manuscript; A. C. Walker, D. L. Gebo, and K. D. Rose for much informative discussion; and A. C. Walker for his generous provision of casts, photographs, and specimens of living and fossil lorises. Asenath Bernhardt took the SEM micrographs. $\mathrm{H}$. Kamel, A. A. el-Ostas, B. Issawi, A. A. Latief-Houdab, and Y. el-Safori were instrumental in providing scientific and logistic expertise in Egypt. We gratefully acknowledge support through NSF grant BNS-82-09937 to E.L.S.

\section{References}

Bown, T. M. et al. (1982). The Fayum primate forest revisited. J. hum. Evol. 11, 606-632.

Dashzeveg, D. \& McKenna, M. C. (1977). Tarsioid primate from the early Tertiary of the Mongolian People's Republic. Acta palaeont. Polon. 22, 119-137.

Fleagle, J. G., Bown, T. M., Obradovich, J. D., and Simons, E. L. (1986). Age of the oldest African anthropoids. Science 234, 1247-1249.

Gazin, C. L. (1962). A further study of the lower Eocene mammalian faunas of southwestern Wyoming. Smithson. misc. Colln. 144, 1-98.

Jacobs, L. L. (1981). Miocene lorisid primates from the Pakistan Siwaliks. Nature 289, $585-587$.

Leakey, L. S. B. (1962). Primates. In (W. W. Bishop, Ed.) The Mammalian Fauna and Geomorphological Relations of the Napak Volcanics, Karamoja, Records of the Geological Survey of Uganda, Entebbe, pp. 1-18.

MacInnes, D. G. (1943). Notes on the East African Miocene primates. J. E. Afr. Uganda nat. hist. Soc. 17, 141-181.

MacPhee, R. D. E. \& Jacobs, L. (1986). Nycticeboides simpsoni and the morphology, adaptations and relationships of Miocene Siwalik Lorisidae. In (K. M. Flanagan \& J. A. Lillegraven, Eds) Vertebrates, Phylogeny and Philosophy: pp. 131-161. Laramie: University of Wyoming.

Maier, W. (1980). Konstruktionsmorphologische untersuchungen am Gebiss der rezenten Prosimiae (Primates) Abh. Senckenb. naturforsch. Gesell. 538, 1-158.

Osborn, H. F. (1908). New fossil mammals from the Fayum, Oligocene, Egypt. Bull. Am. Mus. nat. Hist. 24 $265-272$. 
Rose, K. D. \& Bown, T. M. (1986). Gradual evolution and species discrimination in the fossil record. In (K. M. Flanagan \& J. A. Lillegraven, Eds) Vertebrates, Phylogeny and Philosophy, pp. 119-130. Laramie: Lniv. Wyoming.

Rose, K. D. \& Krause, D. W. (1984). Affinities of the primate Altanius from the early Tertiary of Mongolia. J. Hammal. 65, 721-726.

Russell, D. E. \& Gingerich, P. D. (1980). Ln nouveau primate omomyide dans l'Eocène du Pakistan. C. r. hebd. Seanc. Acad. Sci. Paris 291, 621-624.

Schlosser, M. (1911). Beiträge zur Kenntnis der oligözanen Landsäugetiere aus dem Fayum, Agypten. Palaeont. Geol. Ost. Ling. Beitr. 24, 51-167.

Simons, E. L. \& Bown, T. M. (1985). Afrotarsius, first tarsiiform primate (?Tarsiidae) from Africa. Nature 313, $47 \bar{j}-477$.

Simons, E. L. \& Kay, R. F. (1983). Qatrania, new basal anthropoid primate from the Fayum, Oligocene of Egypt. Vature 304, 624-626.

Simpson, G. G. (1967). The Tertiary lorisiform primates of Africa. Bull. Mus. Comp. Zool. Harvard 136, 39-61. Szalay, F. S. (1976). Systematics of the Omomyidae (Tarsiiformes, Primates). Bull. Am. Mus. nat. Hist. 156, $15 \overline{7}-450$.

Walker. A. C. (1974) A review of the Miocene Lorisidae of East Africa. In (R. D. Martin, G. A. Dovle \& A. C. Walker, Eds) Prosimian Biology, pp. 435-447. London: Duckworth.

Walker, A. C. (1978). Prosimian primates. In (V. J. Maglio \& H. B. S. Cooke, Eds) Evolution of African Mammals, pp. 90-99. Cambridge, Mass.: Harvard Lniversity Press.

Wesselman. H. (1984). The Omo Micromammals. Contributions to Vertebrate Erolution, Vol. 7, 1-165. Basel: Karger. 